\title{
Nutrient Content of Sheep Diets on a Serpentine Barrens Range Site
}

\author{
R.E. ROSIERE AND CHARLES E. VAUGHN
}

\begin{abstract}
Nutritional composition of sheep diets from a serpentine barrens range site was determined at various seasons and stages of plant growth and compared to diets from 3 other annual range sites. Sheep diets from the serpentine site tended to be more nutritious, ranking in the highest pair of sites in digestibility, digestible energy, crude protein, and ether extract, and containing highest concentrations of magnesium. These differences were subtle and had limited application to management. Nutritional differences attributable to plant phenology were inconsistent but more dramatic than those due to site. Late summer and winter were potentially critical periods for brood ewes with protein and energy, respectively, likely to be marginal or possibly deficient. Contents of nutrients and nutritional properties did not differ between available herbage and forage selected by sheep from serpentine barrens.
\end{abstract}

Serpentine, igneous rock formed from peridotite as a complex of hydrous magnesium silicates existing essentially as $\mathrm{H}_{4} \mathrm{MG}_{3} \mathrm{Si}_{2} \mathrm{O}_{9}$ (Gilluly et al. 1975) is the parent material of several soils over an extensive area of the Pacific region including the Sierra Nevada and Coast Ranges of California, Siskiyou Mountains of Oregon, and Wenatchee Mountains of Washington (Whittaker 1954a). California serpentine was described by Kruckeberg (1984a and b). Serpentine soils are low in fertility due to either low levels of calcium (Vlamis and Jenny 1948); high levels of magnesium relative to calcium (Wildman et al. 1968); or low levels of nitrogen, phosphorus, or molybdenum and toxic levels of chromium or nickel (Walker 1954). Coupling these chemical properties with harsh physical factors such as shallowness, stoniness, and steepness creates an edaphic environment supporting such stunted and sparsely populated plants (many endemic) as to constitute a wasteland called "serpentine barrens" (Buol et al. 1980). While serpentine land has low potential for timber production (Storrie and Wieslander 1952), it is widely used as range particularly in coastal northern California where sheep ranching is a traditional livelihood. Sheep are in fact commonly observed grazing the readily distinguishable serpentine barrens apparently in preference to adjacent range sites.

This study was conducted to quantify and evaluate nutritional value of sheep diets from a serpentine range site and to explore causes for a generally perceived preference by sheep for vegetation growing in serpentine soil. To explain this apparent preference, nutritive values from the serpentine range site were compared to those from three nonserpentine range sites. Chemical compositions of soil from the 4 range sites were also determined because these were fundamental to differences among range sites and might explain nutritional differences detected among sheep diets from those sites.

\section{Materials and Methods}

Sheep diets were sampled at various seasons and plant phenolog-

\footnotetext{
Authors are assistant range animal nutritionist, Dept. of Forestry and Resource Management, University of California, Berkeley 94720; and staff research associate, Hopland Field Station.

The authors express appreciation to B.E. Olsen and K.M. Rutz, research assistants, for gross energy determinations; A.H. Murphy, Superintendent Hopland Field Station, for administrative support; and Shu Geng. biometrician-California Agricultural Experiment Station, for statistical counsel.

This article is a contribution from the California Agricultural Experiment Station, Forestry Research Unit. Study supported as Hatch Project 3992.

Manuscript accepted 9 May 1985.
}

ical stages (described under "Collection and Analysis of Diet Samples") in 1981 and 1982 on 4 range sites of annual range on the University of California Hopland Field Station situated in the Coast Mountain Range of northern California (about $160 \mathrm{~km}$ north of San Francisco Bay in Mendocino County).

\section{Description of Study Sites}

The 4 range sites (serpentine barrens site, gravel slope site, loamy upland site, rock outcrop site) from which diets were sampled occurred on 4 Hopland sheep ranges. A description of each site follows.

Serpentine barrens site. Located on Hopland Range, Foster. Soil series was Montara ${ }^{1}$ (Lithic Haploxeroll) having rapid drying and pronounced shrink-swell properties. Serpentine rocks ranged in size from gravel to stones. Rolling topography with mostly westward exposure.

Gravel slope site. Located on Hopland Range, Sl. Soil series were primarily Josephine (Typic Haploxerult) with some Laughlin (Ultic Haploxeroll), Los Gatos (Typic Argixeroll) and Sutherlin (Aquic Haploxeralf). Soils were clay loams with Josephine and Laughlin being shallow and gravely. Slope had south-west aspect.

Loamy upland site. Found on Hopland Range, S3. Soil was mostly Sutherlin plus some Josephine and Laughlin with lower gravel content than in the gravel slope site. Loamy upland occupied hill and ridgetops more than hillsides as in the previous range site.

Rocky outcrop site. Occurred on Hopland Range, D1. Soil was essentially all Sutherlin series with abundant outcroping of sedimentary rock. Topography was rolling with a northerly exposure.

Vegetation of gravel slope, loamy upland, and rock outcrop range sites would be best described as deciduous woodland savannah (Griffin 1977). These range sites were dominated by blue oak (Quercus douglasii), black oak (Q. kelloggii), interior live oak ( $Q$. wislizenii) and madrone (Arbutus menziesii) and, less conspicuous but locally more important, sclerophyllus shrubs such as chamise (Adenostoma fasciculatum) and manzanita (Arctostaphylos spp.). The 3 woodland range sites had herbaceous understories of naturalized annual grasses (mostly Bromus, Aira and Festuca spp.) and forbs (primarily Erodium and Trifolium spp.).

Vegetation of the serpentine barrens site was, by contrast, annual grassland (Heady 1977). This range site was populated by depauperate specimens of typical annual species and serpentineendemic herbs but largely devoid of woody plants.

Compositions of the herbaceous understories of plant communities were determined by step-point procedure (Evans and Love 1957) at period of peak standing crop and are shown in Table 1. Annual production of range biomass (Table 1) was calculated by clipping and weighing caged and grazed herbage periodically throughout the grazing year (fall germination to fall germination) by methodology described by Mannetje (1978). Grazing year degree of use was determined from these biomass data.

\section{Collection and Analysis of Diet Samples}

Samples of sheep diets were collected using 6 esophagealfistulated crossbred wool ewes. Collections were made during 6 seasons/plant phenological periods: (1) fall/start of green feed

\footnotetext{
ISoil classification follows Soil Survey Staff (1975).
}

2Plant nomenclature from Munz and Keck (1973). 
Table 1. Species" composition ${ }^{b}$ (percent) and herbage yield ${ }^{c}\left(\mathbf{k g} / h_{a}\right)$ of four annual range sites in coastal northern Callfornia.

\begin{tabular}{|c|c|c|c|c|c|}
\hline Serpentine barrens site & & Nonserpentine sites: & Loamy upland & Gravel slope & Rock outcrop \\
\hline Grasses: & & Grasses: & & & \\
\hline Soft chess & & Silver hairgrass & & & \\
\hline $\begin{array}{l}\text { (Bromus mollis) } \\
\text { Gray's fescue }\end{array}$ & 8 & $\begin{array}{l}\text { (Aira caryophyllea) } \\
\text { Wild oats }\end{array}$ & 10 & 26 & 6 \\
\hline $\begin{array}{l}\text { (Festuca grayi) } \\
\text { Mouse barley }\end{array}$ & 4 & $\begin{array}{l}\text { Avena barbata \& fatua) } \\
\text { Soft chess }\end{array}$ & 7 & 1 & 2 \\
\hline (Hordeum leporinum) & 7 & $\begin{array}{l}\text { (Bromus mollis) } \\
\text { Ripgut brome }\end{array}$ & 27 & 33 & 52 \\
\hline Rush: & & (Bromus rigidus) & 10 & 5 & 2 \\
\hline (Juncus bolanderi) & $\mathbf{T}$ & Red brome & & & \\
\hline & & (Bromus rubens) & 1 & 3 & - \\
\hline Forbs: & & Other annual Bromus & - & - & 3 \\
\hline Mountain dandelion & & Medusahead & & & \\
\hline $\begin{array}{l}\text { (Agoseris heterophylla) } \\
\text { Douglas sandwort }\end{array}$ & 8 & $\begin{array}{l}\text { (Elymus caput-medusae) } \\
\text { Annual fescues }\end{array}$ & 7 & 一 & $\mathbf{T}$ \\
\hline $\begin{array}{l}\text { (Arenaria douglasii) } \\
\text { Goldfields }\end{array}$ & 1 & $\begin{array}{l}\text { (Festuca spp.) } \\
\text { Wild barleys }\end{array}$ & 3 & 1 & 13 \\
\hline (Baeria chrysostoma) & 16 & (Hordeum spp.) & 1 & $\mathbf{T}$ & 6 \\
\hline Three-colored gilia & & Other annual Gramineae & 1 & $\mathbf{T}$ & $\mathbf{I}$ \\
\hline (Gilia tricolor) & 1 & Purple needlegrass & & & \\
\hline Common spikeweed & & (Stipa pulchra) & 1 & - & $\mathbf{T}$ \\
\hline (Hemizonia pungens) & 5 & & & & \\
\hline Pepperweed & & Forbs: & & & \\
\hline (Lepedium nitidum) & $\mathrm{T}$ & Filaree & & & \\
\hline Microseris & & (Erodium botrys \& cicutarium) & 16 & 11 & $\mathbf{T}$ \\
\hline (Microseris douglasii) & 11 & Geranium & & & \\
\hline $\begin{array}{l}\text { California plantain } \\
\text { (Plantago hookeriana }\end{array}$ & & $\begin{array}{l}\text { (Geranium dissectum \& molle) } \\
\text { Lupine }\end{array}$ & - & - & $\mathbf{T}$ \\
\hline var californica) & 14 & (Lupinus spp.) & 2 & 1 & 13 \\
\hline Plcctritis & & Clovers & & & \\
\hline (Plectritis cilosa) & 9 & (Trifolium spp.) & 4 & 8 & 2 \\
\hline Rancheria clover & & Miscellaneous & 10 & 11 & 13 \\
\hline $\begin{array}{l}\text { (Trifolium albopurpureum) } \\
\text { Miscellaneous }\end{array}$ & $\begin{array}{l}6 \\
5\end{array}$ & & & & \\
\hline Moss (Musci) & 5 & & & & \\
\hline Peak Standing Crop & 441 & & 1383 & 732 & 1399 \\
\hline $\begin{array}{l}\text { Mean Herbage at Sampling } \\
\text { Periods }\end{array}$ & 282 & & 1087 & 533 & 699 \\
\hline
\end{tabular}

aplant names from Munz and Keck (1973).

betermined at peak standing crop using step point method.

'Under grazing.

$\mathrm{T}=$ Trace (less than $1 \%$ ).

period (seedling stage), mid December; (2) winter/early green feed period (seedling-prebloom), early February; (3) early-mid spring/middle of green feed period (early bloom stage), early April; (4) late spring/peak standing crop (full-bloom), mid May; (5) mid summer/mature plants (seed ripe-seed shatter), mid July; (6) late summer/disintegrating plants (straw), mid September. Samples of available herbage were obtained during this same period by clipping (ground level) plants occurring in ten $.09-\mathrm{m}^{2}$ plots. These plots were randomly located within areas from which forage samples were selected by the fistulated sheep. Collected samples were dried in large forced draft ovens $\left(55^{\circ} \mathrm{C}\right)$ and then ground through a Wiley mill (1-mm screen). Nutritive analyses were done by procedures given by Association of Official Agricultural Chemists (1965) for dry matter, ash, ether extract, and crude protein. For in vitro organic matter digestibility, the two-stage procedure of Tilley and Terry (1963) was used. Fiber constituents (neutral detergent fiber, acid detergent fiber, acid detergent lignin, cellulose, hemicellulose, acid insoluble ash) were assayed by methods of Goering and Van Soest (1975). Heats of combustion were determined using adiabatic calorimetry (Parr Instrument Company, 1981). Digestible energy was estimated by multiplying gross energy by organic matter digestion coefficients. This was based on the assumption that digestibility of energy bearing components was approximately equal to that of total organic matter content (Rosiere and Torell 1985). Mineral content was determined on nitric-perchloric acid digests; phosphorus with vanadate-molybdate yellow color development and calcium, magnesium, and potassium by atomic absorption spectrophotometry (Varian Techtron 1972).

\section{Soil Analysis}

Since edaphic features were the primary characteristics or bases for the 4 range sites studied, chemical compositions of their soils were determined (Table 2). Soil samples were collected from the surface $15 \mathrm{~cm}$, air dried, and sieved $(2 \mathrm{~mm})$. Available soil $P$ was determined by the Bray and Kurtz (1945) No. 1 method, available S was determined turbidimetrically on a calcium phosphate-acetic acid extract described by Hoeft et al. (1973), and available (or total inorganic) $\mathbf{N}$ was determined by the steam-distillation method described by Bremner (1965). Exchangeable soil $\mathrm{Ca}, \mathrm{Mg}, \mathrm{K}$, and $\mathrm{Na}$ were determined by atomic absorption spectrophotometry following extraction with neutral $N$ ammonium acetate. Exchange acidity was determined by a barium chloride-triethanolamine method (Peech, 1965). Soil pH was measured with a pH meter in a 1:2.5 soil water suspension.

\section{Statistical Evaluation}

Biometrical techniques were conducted according to Steel and 
Table 2. Some soil chemical characteristics of four typical northern California annual range sites.

\begin{tabular}{|c|c|c|c|c|c|c|c|c|c|c|}
\hline \multirow[b]{2}{*}{ Range Site } & \multirow[b]{2}{*}{$\begin{array}{l}\text { Dominant } \\
\text { Soil Series }\end{array}$} & \multicolumn{5}{|c|}{ Exchangeable } & \multirow[b]{2}{*}{$\mathrm{pH}$} & \multicolumn{3}{|c|}{ Available } \\
\hline & & $\mathrm{Ca}$ & $\mathbf{M g}$ & $\begin{array}{l}\mathrm{K} \\
\mathrm{a} / 100\end{array}$ & $\mathrm{Na}$ & $\mathbf{H}$ & & $\mathbf{N}$ & $\mathbf{P}$ & $\mathbf{S}$ \\
\hline Serpentine barrens & Montara & 1.2 & 24.2 & 0.3 & Tr. & 6.3 & 6.8 & 6.9 & 3 & 3.0 \\
\hline Gravel Slope & Josephine & 4.2 & 1.1 & 0.4 & Tr. & 6.3 & 5.8 & 9.1 & 48 & 4.5 \\
\hline Loamy upland & Sutherlin & 3.4 & 6.8 & 0.4 & Tr. & 4.8 & 6.1 & 5.8 & 3 & 5.0 \\
\hline Rock outcrop & Sutherlin & 2.0 & 11.4 & 0.4 & Tr. & 4.7 & 6.2 & 7.7 & 7 & 6.2 \\
\hline
\end{tabular}

Torrie (1980). Effects of seasons on nutritional value of diets were analyzed by making comparisons between 6 periods of season and phenological stage, the treatments, in one-way analysis of variance (completely random design with unequal replication). Seasonal means of nutrients and energy, fiber, and digestibility were separated $(P<.01)$ by Fisher's protected least significant difference (separation of means only if AOV F values were significant). Comparison of diets from serpentine barrens to those from other sites was made by viewing sites and seasonal periods as treatments in an unbalanced $4 \times 6$ factorial experiment using analysis of variance of completely randomized design. When $F$ values were significant $(P<.05)$ mean values were separated by Tukey's honestly significant difference procedure. Differences in nutritional variables between sheep diets and range herbage over all seasons were tested for significance using Student's $t$ as were differences in utilization between serpentine and nonserpentine locations.

\section{Results and Discussion}

Nutritive content of sheep diets from serpentine barrens is reported as organic matter digestibility, energy content, crude protein, ether extract, fiber constituents, and minerals (Table 3). Rosiere and Torell (1985) reported detailed nutritive composition of diets from the 3 nonserpentine range sites. Sheep diets from serpentine barrens varied significantly over seasons and from other sites. There were differences among sites for all nutrients, energy digestibility, and fiber portions except neutral detergent fiber and cellulose (Table 4). Highly significant seasonal differences occurred on serpentine range for all organic components except hemicellu- lose (Table 3). Significant site $X$ season interactions were detected for in vitro digestibility, digestible energy, ether extract, and acid detergent fiber.

Differences in nutritional quality of sheep diets among sites over the 6 seasonal/phenological periods of this trial contrasted with data from a concurrent study by Rosiere and Torell (1985). They sampled during 8 periods, including early and late summer seasons of the previous year, and found no significant differences in dietary quality among the 3 nonserpentine ranges. Changes in nutrient content with progression of growing season and plant development were documented in the companion experiment.

Though statistical differences existed among diets from the 4 sites, these relations were general and inconsistent and their biological significance was unclear. Serpentine barrens tended to yield forage which was more nutritious than that from other range sites. It ranked in the highest pair of sites for digestibility, crude protein, and ether extract and was in the lower pair for lignin. It was in the highest pair for digestible energy on an organic matter basis but was intermediate in digestible energy when expressed as dry matter. The loamy upland site rated with serpentine barrens in digestibility and was high in digestible energy, but fell in the lowest pair of sites for crude protein and ether extract. Forage selected from the gravel slope site compared with that from serpentine barrens in ether extract but ranked in the lowest pair of sites for protein, energy, and digestibility. Diets from this steep, shallow site also contained significantly less hemicellulose than those from other sites and had the highest measured concentration of lignin. The rock outcrop site provided diets with nutritional contents interme-

Table 3. Nutritional composition ${ }^{\text {ab }}$ of ewe diets from a serpentine barrens range site in northern California at various seasons.

\begin{tabular}{|c|c|c|c|c|c|c|}
\hline & \multicolumn{6}{|c|}{ Season } \\
\hline & Fall & Winter & Mid Spring & Late Spring & Mid Summer & Late Summer \\
\hline Crude Protein & $16.2 \pm 2.5^{\text {ef }}$ & $17.4 \pm 2.4^{e}$ & $13.2 \pm 1.5^{\mathrm{fg}}$ & $11.6 \pm 1.3^{\mathrm{zh}}$ & $9.1 \pm .4^{\mathrm{hi}}$ & $7.6 \pm 1.3^{i}$ \\
\hline Ether Extract & $1.6 \pm .2^{\mathrm{fg}}$ & $1.5 \pm .2^{8}$ & $2.0 \pm .1^{f}$ & $2.5 \pm .0^{\circ}$ & $2.1 \pm .1^{\text {ot }}$ & $1.5 \pm .1$ \\
\hline Neutral Detergent Fiber & $46.7 \pm 2.4^{\mathrm{fg}}$ & $50.8 \pm .5^{f}$ & $41.8 \pm .7^{\mathrm{g}}$ & $47.9 \pm 2.5^{\mathrm{tg}}$ & $59.0 \pm 2.7^{\circ}$ & $51.0 \pm 1.6^{f}$ \\
\hline Acid Detergent Fiber & $32.0 \pm 1.5^{8}$ & $36.3 \pm .9^{f}$ & $27.4 \pm .7^{\mathrm{h}}$ & $32.0 \pm 1.6^{\mathrm{g}}$ & $42.2 \pm .9^{\circ}$ & $38.2 \pm .5^{f}$ \\
\hline Acid Detergent Lignin & $4.3 \pm .3^{f}$ & $5.8 \pm 1.0^{\circ f}$ & $4.1 \pm .3^{f}$ & $5.5 \pm .1^{\mathrm{ef}}$ & $6.9 \pm .3^{\mathrm{e}}$ & $5.1 \pm .7^{\text {ef }}$ \\
\hline Hemicellulose & $14.7 \pm .9$ & $14.5 \pm 1.2$ & $14.3 \pm .5$ & $15.9 \pm 1.0$ & $16.8 \pm 1.9$ & $12.8 \pm 1.4$ \\
\hline Cellulose & $22.6 \pm 1.8^{h}$ & $24.3 \pm 1.2^{R}$ & $19.8 \pm .6^{\mathrm{i}}$ & $23.4 \pm 1.7^{\mathrm{zh}}$ & $29.3 \pm 1.0^{\circ}$ & $27.8 \pm .6^{t}$ \\
\hline $\operatorname{Ash}^{c}$ & $14.40 \pm .63$ & $15.78 \pm .37$ & $13.62 \pm 1.66$ & $12.77 \pm .41$ & $13.72 \pm .39$ & $13.24 \pm .22$ \\
\hline Calcium $^{\mathrm{C}}$ & $.17 \pm .02$ & $.32 \pm .02$ & $.25 \pm .02$ & $.28 \pm .02$ & $.29 \pm .02$ & $.26 \pm .02$ \\
\hline Phosphorus & $.29 \pm .02$ & $.35 \pm .02$ & $.29 \pm .02$ & $.38 \pm .01$ & $.29 \pm .04$ & $.23 \pm 0$ \\
\hline Potassium $^{\mathrm{c}}$ & $1.74 \pm .17$ & $1.40 \pm .14$ & $1.38 \pm .02$ & $1.51 \pm .05$ & $.71 \pm .03$ & $.47 \pm .06$ \\
\hline Magnesium & $.58 \pm .05$ & $.65 \pm .09$ & $.58 \pm .05$ & $.76 \pm .10$ & $.49 \pm .04$ & $.81 \pm .06$ \\
\hline Silicad & $5.29 \pm .37$ & $5.06 \pm .43$ & $3.46 \pm .26$ & $3.12 \pm .22$ & $5.99 \pm .36$ & $5.29 \pm .37$ \\
\hline \multicolumn{7}{|l|}{ In vitro organic } \\
\hline matter digestibility & $62.7 \pm 2.0^{\mathrm{ef}}$ & $58.2 \pm 2.2^{f g}$ & $72.1 \pm 1.9^{\mathrm{e}}$ & $62.5 \pm 7.4^{f}$ & $52.6 \pm 2.2^{8}$ & $60.6 \pm 1.7^{f 8}$ \\
\hline \multicolumn{7}{|l|}{ Gross energy (Mcal/kg dry } \\
\hline \multicolumn{7}{|l|}{ Digestible energy (Mcal/kg } \\
\hline dry matter) & $2.95 \pm .09^{\text {eff }}$ & $2.53 \pm .08^{\mathrm{fg}}$ & $3.08 \pm .07^{e}$ & $2.54 \pm .11^{\mathrm{fg}}$ & $2.17 \pm .06^{\mathrm{h}}$ & $2.43 \pm .07^{\mathrm{gh}}$ \\
\hline
\end{tabular}

Mean \pm SE.

(\%) except gross and digestible energy; (dry matter basis) except in vitro digestibility.

cSheep saliva contained potassium, phosphorus and calcium at $.056, .025$ and $.0025 \%$, respectively.

Measured as acid-insoluble ash.

${ }^{M}$ Means in the same row having different superscripts differ $(\boldsymbol{P}<.01)$. 
Table 4. Mean contents" of nutritional variables in ewe diets from four annual range sites (averaged over six seasons) in coastal northern California.

\begin{tabular}{|c|c|c|c|c|}
\hline \multirow[b]{2}{*}{ Nutritional Variable } & \multicolumn{4}{|c|}{ Range Site } \\
\hline & Serpentine Barrens & Gravel Slope & Loamy Upland & Rock Outcrop \\
\hline Organic Matter Digestibility & $62.2^{\text {bc }}$ & $62.6^{b}$ & $55.6^{d}$ & $58.7^{\text {cd }}$ \\
\hline Digestible Energy & $2.62^{\text {be }}$ & $2.53^{\mathrm{e}}$ & $2.76^{\mathrm{b}}$ & $2.67^{b}$ \\
\hline Crude Protein & $12.5^{\mathrm{b}}$ & $9.9^{\mathrm{cd}}$ & $8.8^{\mathrm{d}}$ & $11.0^{\mathrm{bc}}$ \\
\hline Ether Extract & $1.9^{\mathrm{bc}}$ & $1.7^{\mathrm{cd}}$ & $2.2^{\mathrm{b}}$ & $1.5^{\mathrm{c}}$ \\
\hline Neutral Detergent Fiber & 49.5 & 47.2 & 46.6 & 50.3 \\
\hline Acid Detergent Fiber & 34.7 & 34.3 & 37.0 & 34.8 \\
\hline Acid Detergent Lignin & $5.3^{\mathrm{c}}$ & $5.8^{\mathrm{c}}$ & $9.2^{\mathrm{b}}$ & $8.1^{\mathrm{b}}$ \\
\hline Cellulose & 24.6 & 25.6 & 25.7 & 24.2 \\
\hline Hemicellulose & $14.8^{\mathrm{b}}$ & $13.0^{\mathrm{b}}$ & $10.0^{\mathrm{c}}$ & $15.5^{b}$ \\
\hline Magncsium & $0.66^{\mathrm{b}}$ & $0.32^{c}$ & $0.16^{d}$ & $0.40^{c}$ \\
\hline
\end{tabular}

All values are percent (DM basis) except Digestible Energy (Mcal/kg dry matter).

bed Means in the same row having different superscripts differ $(P<01)$.

Table 5. Mean contents" of nutritional variables in ewe diets during six seasons (averages of four range sites) in coastal northern California.

\begin{tabular}{|c|c|c|c|c|c|c|}
\hline \multirow[b]{2}{*}{ Nutritional Variable } & \multicolumn{6}{|c|}{ Season } \\
\hline & Fall & Winter & Mid Spring & Late Spring & Mid Summer & Late Summer \\
\hline Organic Matter Digestibility & $62.8^{\mathrm{c}}$ & $55.4^{d}$ & $72.1^{b}$ & $58.1^{\mathrm{c}}$ & $53.4^{d}$ & $57.9^{d}$ \\
\hline Digestible Energy & $2.88^{\mathrm{c}}$ & $2.4^{\mathrm{d}}$ & $3.17^{\mathrm{b}}$ & $2.49^{\mathrm{d}}$ & $2.33^{\circ}$ & $2.49^{d}$ \\
\hline Crude Protein & $13.6^{\mathrm{b}}$ & $12.4^{\text {bc }}$ & $12.0^{b c}$ & $11.1^{\mathrm{c}}$ & $7.4^{\mathrm{cd}}$ & $7.0^{d}$ \\
\hline Ether Extract & $2.0^{\mathrm{b}}$ & $1.9^{\mathrm{bc}}$ & $2.1^{\mathrm{b}}$ & $2.1^{\mathrm{b}}$ & $1.4^{\mathrm{ed}}$ & $1.2^{\mathrm{d}}$ \\
\hline Neutral Detergent Fiber & $46.1^{c}$ & $52.8^{\mathrm{b}}$ & $41.9^{\mathrm{c}}$ & $45.0^{c}$ & $53.5^{b}$ & $51.9^{b}$ \\
\hline Acid Detergent Fiber & $33.8^{\mathrm{c}}$ & $38.7^{\mathrm{b}}$ & $28.8^{d}$ & $31.7^{\text {ed }}$ & $39.0^{\mathrm{b}}$ & $39.0^{\mathrm{b}}$ \\
\hline Acid Detergent Lignin & $5.9^{\mathrm{ed}}$ & $8.5^{b}$ & $5.0^{\mathrm{d}}$ & $6.2^{\mathrm{cd}}$ & $7.9^{\mathrm{bc}}$ & $6.9^{\mathrm{bcd}}$ \\
\hline Cellulose & $23.5^{\mathrm{cd}}$ & $25.4^{\text {bc }}$ & $21.0^{\mathrm{d}}$ & $23.6^{\mathrm{cd}}$ & $27.9^{b}$ & $28.5^{\mathrm{b}}$ \\
\hline Hemicellulose & 12.3 & 14.7 & 13.2 & 13.0 & 14.6 & 12.9 \\
\hline Magnesium & $.36^{c}$ & $.37^{\mathrm{b}}$ & $.40^{\mathrm{b}}$ & $.48^{\mathrm{b}}$ & $.32^{c}$ & $.42^{\mathrm{b}}$ \\
\hline
\end{tabular}

All values are percent (DM basis) except Digestible Energy (Mcal/kg dry matter).

Means in the same row having different superscripts differ $(P<01)$.

diate between loamy uplands and gravel slopes, but these were more similar to the latter, which appeared to furnish the least nutritious forage of the 4 range sites.

Seasonal variation in nutritional content for the 4 range sites (Table 5) followed characteristic changes coincident with advancement of plant growth and maturity (Van Soest 1982). However, these patterns and relations among nutritive characters within seasons/phenological stages were not clear-cut. Diets were most digestible and had highest contents of digestible energy in fall and mid spring when concentrations of cellulose and acid detergent fiber tended to be lowest. However, crude protein was higher in fall than in late spring and ether extract was lower in summer than in spring diets. Forage was least nutritious in summer periods when lowest digestible energy, crude protein, and digestibility coincided. This was not absolute, though, as digestibility was as great in late summer as in fall or late spring, and energy value in late spring (at peak standing crop) did not differ from that in late summer (least available herbage). Protein was clearly lowest $(P<01)$ at summer's end, but acid detergent fiber and lignin and ether extract at this period did not differ from that in winter forage.

The comparatively high contents of fiber and lignin in winter diets, together with relatively low digestibility and an intermediate energy level and a paucity of herbage, indicated that winter could be a nutritionally stressful season for sheep irrespective of high protein contents. Examination of winter diets from nonserpentine sites also suggested that winter could be a critical season (Rosiere and Torell 1985). Viewed generally, and in relation to probable low forage intakes due to limited herbage and high fiber/lignin levels, it seemed that nutritional deficiencies would be most likely in summer and winter with minimal factors being protein and energy, respectively. Likelihood of deficiencies would, of couse, depend on nutrient requirements as affected by reproductive status and performance. Crude protein levels in forage selected by ewes satisfied requirements, as stated by National Research Council (1975) in percentage of diet, for maintenance at all sampling periods except late summer, and for pregnancy or lactation except in mid and late summer. Digestible energy requirements (Mcal $/ \mathbf{k g}$ ) were met for ewe maintenance during all periods, but energy concentrations in summer periods were lower than late gestation and lactation standards. Problems with dietary deficiencies could be eliminated or reduced by scheduling breeding and marketing so that advanced pregnancy and lactation coincided with lower quality diets (summer and winter) for a minimum duration.

Minerals other than magnesium were not evaluated statistically because saliva from fistulated sheep contained quantities of elements (Table 3) which likely biased levels measured in esophageal extrusa. However, it was felt that an adequate characterization of sheep diets, especially on serpentine barrens noted for an unusual magnesium: calcium ratio, should include some mineral analyses. Magnesium contents were not contaminated by saliva and were highest on the serpentine site, lowest on the loamy upland site, and intermediate on outcrop and gravel slope sites (Table 4). Concentrations of magnesium were lowest in fall and midsummer diets but did not differ significantly among other seasons (Table 5). Magnesium concentrations in soil from serpentine barrens were measured at concentrations that averaged 3.7 times greater than that of nonserpentine soils (Table 2). Herbage from serpentine barrens contained 4.5 times more magnesium than herbage from loamy upland and gravel slope sites (.65 vs .14\%). Magnesium in herbage from the rock outcrop site $(.60 \%)$ did not differ from that in serpentine herbage. Magnesium contents of diets from all sites exceeded the $.04-.08 \%$ requirement (National Research Council 
1975) by at least four-fold. Calcium in forage selected from serpentine range (Table 3) was below upper levels of National Research Council requirements at all seasons and it must be assumed that contents were somewhat overestimated by salivary calcium. High levels of magnesium and low levels of calcium in serpentinederived soils detected in this and previous studies (Vlamis and Jenny 1948, Wildman et al. 1968) were reflected not only in composition of plants growing in serpentine soil but also in diets of animals eating these plants. These data indicated that ewe diets were marginal in calcium, but there were no signs of calcium deficiency in brood ewes grazing these ranges yearlong with no mineral supplementation.

These results agreed with findings from agronomic species grown on serpentine soils where plant productivity and foliage mineral contents were affected by calcium availability (Jones and Ruckman 1974) and calcium/magnesium ratios (Wallace et al. 1975, Jones et al. 1976), but deviated from outcomes seen by Wallace et al. (1975) for native shrubs which under greenhouse conditions were unaffected by adverse calcium/magnesium ratios and presence of heavy metals (lithium, nickel, chromium).

Selective grazing on the serpentine barrens site by sheep was not clearly substantiated in this investigation. There was no significant difference between range herbage and sheep-selected forage for any nutritional variable on an annual basis. This contrasted with sheep diets from other annual range sites. On both grass-woodland and improved grassland range, Rosiere and Torell (1985) documented grazing selectivity though it was infrequent and less pronounced than that reported by workers for other range types. On serpentine, relations between nutrient contents in sheep diets and those in range herbage varied with seasons, but statistical tests could not be conducted on a seasonal basis since there was no replication of the serpentine site. Magnesium, for instance, averaged two-fold greater in diets but was measured higher in herbage during half the sampling periods, so mean annual contents did not differ significantly between diets and herbage. Comparisons of animal-selected and available feed were further complicated by sampling, and the fact that on any given range theoretically there was only one composite of nutrients in herbage, but there were potentially as many diets as sheep grazing that range. Indiscriminate consumption of nutritional variables was consistent with the proposal of Arnold (1960) that there should be less selective grazing of more palatable species and less mature plants.

Limited selectivity in grazing yet obtainment of more nutritious diets on serpentine barrens may explain attractiveness of this site to sheep. They could obtain higher quality forage while grazing less discriminately and thus meet nutrient needs more effectively, though this might be offset by lower site productivity (Table 2) which could reduce forage intake or increase grazing time and cncrgy cxpcnditure. Less standing crop or low growth form of plants could also have been a factor in apparent preference for serpentine range. Throughout this trial sheep were frequently seen foraging in closely grazed or even bare areas while ignoring adjacent bounteous parcels. Spot-grazing often resulted in patchworks of nonuse even on heavily grazed rangeland where it resulted in partial starvation of sheep amongst plentiful feed supplies. This phenomenon was particularly conspicuous in the straw stage of the dormant period on range with serpentine sites and on rock outcrop sites with homogenous stands of soft chess (Bromus mollis), an annual grass widely regarded as more palatable at maturity than associated species (Bentley and Talbot 1951, George et al. 1983).

Endemic species may have been a further factor involved in attraction of sheep to serpentine sites. The unique serpentine plant community did, despite low standing crop, produce herbage that was more nutritious. Serpentine plants may have been more attractive to sheep because of a different chemical composition reflective of that in the soil (e.g., higher contents of magnesium).

Degree of use on the serpentine site during the 1981-1982 grazing was $69 \%$, but approximately two-thirds of herbage remaining at year's end was unpalatable common spikeweek (Hemizonia pungens) so utilization of edible portions was realistically nearer to $90 \%$. From 1958 to 1983 utilization of herbage on this site at peak standing crop averaged $62 \%$ compared to a mean of $39 \%(P<0.1)$ at 5 nonserpentine locations in Foster Range (A.H. Murphy unpublished data), indicating a preference by sheep for serpentine range. It was observed that heavy grazing had a probable effect on species composition or plant physiognomy of serpentine barrens communities. In exclosures and areas between rocks with limited exposure to grazing, purple needlegrass (Stipa pulchra), the perennial dominant of the original California bunchgrass region (Heady 1977), and California melic (Melica californica) were more conspicuous than in heavily grazed range populated with forbs and annual grasses. Latimer (1984) also noted that purple needlegrass was a conspicuous member of grassland communities on serpentine sites but was rare on nonserpentine soils. He found that soft chess and wild oats (Avena barbata) were the only annual grasses common on serpentine. From these observations it seemed likely that serpentine barrens under heavy grazing was partly a result of plant and animal interactions and not just a product of unusual pedological/mineralogical conditions. Groups of range plants associated with serpentine soils should probably be viewed from a perspective of grazing history as they may exist, using Daubenmire (1968) classification, as a "zoo-edaphic climax" (vegetation induced by animals as well as soil).

\section{Literature Cited}

Association of Official Agricultural Chemists. 1965. Official Methods of Analysis (10th Ed.). Association of Official Agricultural Chemists. Washington, DC.

Arnold, G.W. 1960. Selective grazing by sheep of two forage species at different stages of growth. Australian J. Agr. Res. 11:1026-1033.

Bentley, J.R., and M.W. Talbot. 1951. Efficient use of annual plants on cattle ranges in the California foothills. USDA Circ. No. 870.

Bray, R.H., and L. Kurtz. 1945. Determination of total, organic, and available forms of phosphorus in soils. Soil Sci. 59:39-45.

Bremner, J.M. 1965. Inorganic forms of nitrogen. In: C.A. Black et al. (Ed.) Methods of Soil Analysis. Part 2. Agronomy 9:1179-1237.

Buol, S.W., F.D. Hole, and R.J. McCracken. 1980. Soil Genesis and Classification (2nd Ed.). Iowa State Univ. Press, Ames.

Daubenmire, R. 1968. Plant Communities - A Textbook of Plant Synecology. Harper \& Row Pub., New York.

Evans, R.A., and R.M. Love. 1957. The step-point method of sampling - a practical tool in range research. J. Range Manage. 10:208-212.

George, M.R., T.E. Adams, and W.J. Clawson. 1983. Seeded range plants for California. Univ. California Agr. Ext. Leaf. No. 21344.

Gilluly, J., A.C. Waters, and A.O. Woodford. 1975. Principles of geology (4th Ed.). W.H. Freeman \& Co., San Francisco.

Goering, H.K., and P.J. Van Soest. 1975. Forage fiber analyses (Apparatus, reagents, procedures, and some applications). Agr. Handbook No. 379. USDA ARS, Washington, DC.

Griffin, J.R. 1977. Oak woodland. In: M.G. Barbour and J. Major (Eds.) Terrestrial vegetation of California. John Wiley \& Sons, New York.

Heady, H.F. 1977. Valley grassland. In: M.G. Barbour and J. Major (Eds.) Terrestrial Vegetation of California. John Wiley \& Sons, New York.

Hoeft, R.G., L.M. Walsh, and D.R. Keeney. 1973. Evaluation of various extracts for available soil sulfur. Soil Sci. Amer. Proc. 37:401-404.

Jones, M.B., and J.E. Ruckman. 1974. Available calcium and response of sub-clover growing on serpentine-type soils. Australian Soil Sci. Conf., Melbourne, Victoria.

Jones, M.B., C.E. Vaughn, and R.S. Harris. 1976. Critical Ca levels and $\mathrm{Ca} / \mathrm{Mg}$ ratios in Trifolium subterraneum $\mathrm{L}$. grown on serpentine soils. Agron. J. 68:756-759.

Kruckeberg, A. 1984a. California's serpentine. Fremontia 11:11-17.

Kruckeberg, A. 1984b. The flora of California's serpentine. Fremontia 11:3-10.

Latimer, H. 1984. Serpentine flora: notes on prominent sites in Californiaeastern Fresno County. Fremontia 11:29-30.

Mannetje, L.'t. 1978. Measuring quantity of grassland vegetation. In: L.'t Mannetje (Ed.) Measurement of Grassland Vegetation and Animal Production. Bull. 52, Commonwealth Bureau of Pastures and Field Crops: Commonwealth Bureaux, Farnham Royal, Bucks, England. 
Munz, P.A., and D.D. Keck. 1973. A California Flora and Supplements Univ. California Press, Berkeley.

National Research Council. 1975. Nutrient requirements of domestic animals, No. 5. Nutrient Requirements of Sheep. Fifth Revised Ed. Nat. Acad. Sci.-Nat. Res. Counc., Washington, DC.

Parr Instrument Company. 1981. Instructions for the 1241 Adiabatic Oxygen Bomb Calorimeter. Manual No. 160. Parr Instrument Co. Moline, Ill.

Peech, M. 1965. Exchange acidity. In. C.A. Black et al. (Ed.) Methods of Soil Analysis. Part 2. Agronomy 9:905-913.

Rosiere, R.E., and D.T. Torell 1985 . Nutritive value of sheep diets from coastal California annual range. Hilgardia (Vol. 53 in press).

Soil Survey Staff. 1975. Soil taxonomy. A basic system of soil classification for making and interpreting soil surveys. Agr. Handbook No. 436. USDA Soil Conserv. Serv., Washington, DC.

Steel, R.G., and J.H. Torrie. 1980. Principles and procedures of statistics -A biometrical approach (2nd Ed.). McGraw-Hill, Inc.

Storrie, R.W., and A.W. Wieslander. 1952. Dominant soils of the redwood-Douglas fir region of California. Soil Sci. Soc. Amer. Proc. 16:163-167.
Tilley, J.M.A., and R.A. Terry. 1963. A two-stage technique for the in vitro digestion of forage crops. J. British Grassl. Soc. 18:104-111.

Van Soest, P.J. 1982. Nutritional ecology of the ruminant. O\&B Books, Inc., Corvallis, Ore.

Varian Techtron. 1972. Analytical methods for flame spectroscopy. Varian Techtron Property, Ltd. Melborne, Australia.

Vlamis, J., and H. Jenny. 1948. Calcium deficiency in serpentine soils as revealed by adsorbent technique. Science 107:549-551.

Walker, R.B. 1954. The ecology of serpentine soils II. Factors affecting plant growth on serpentine soils. Ecology 35:259-266.

Wallace, A., M.B. Jones, and O.R. Lunt. 1975. Heavy metal uptake by plants from serpentine soils. Internat. Conf. on Heavy Metals in the Environment, Toronto, Can.

Whittaker, R.H. 1954. The ecology of serpentine soils I. Introduction. Ecology 35:258.

Wildman, W.E., M.L. Jackson, and L.D. Whittig. 1968. Iron-rich montmorillonite formation in soils derived from serpentine. Soil Sci. Soc. Amer. Proc. 32:787-794. 